\title{
Maize-mucuna rotation: An alternative technology to improve water productivity in smallholder farming systems
}

\author{
P. Masikati ${ }^{a, *}$, A. Manschadi ${ }^{b}$, A. van Rooyen ${ }^{\text {a }}$, J. Hargreaves ${ }^{c}$ \\ a International Crops Research Institute for the Semi-arid Tropics (ICRISAT), PO Box 776, Bulawayo, Zimbabwe \\ ${ }^{\mathrm{b}}$ Center for Development Research (ZEF), Walter-Flex Strasse 3, D53113 Bonn, Germany

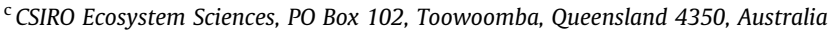

\section{A R T I C L E I N F O}

\section{Article history:}

Received 15 January 2013

Received in revised form 30 August 2013

Accepted 4 September 2013

Available online 5 November 2013

\section{Keywords:}

Maize-mucuna rotations

Water productivity

APSIM

Smallholder farming systems

\begin{abstract}
A B S T R A C T
Rain-fed crop production systems in the semi-arid tropics of Zimbabwe are characterized by low water productivity (WP), which is partly attributed to inherent low soil fertility, and further exacerbated by continuous cropping without addition of adequate organic and inorganic fertilizers due to unavailability and high costs. A simulation modeling approach was used to evaluate potential interventions that can be used as entry points to improve crop water productivity. Low-cost interventions that use locally available organic inputs were evaluated using the Agriculture Production Systems sIMulator (APSIM). The farmer practice (FP) was compared to interventions comprising manure application (MN) and maize-mucuna rotation (MMR). Their potential effects on crop water productivity, dynamics of soil organic carbon (SOC) and total nitrogen (TN) were assessed. Average maize grain water productivity was $0.32,0.40$ and $0.70 \mathrm{~kg} \mathrm{~m}^{-3}$ under the FP, MN and MMR treatments, respectively, while that of mucuna biomass (Mucuna pruriens) was $1.34 \mathrm{~kg} \mathrm{~m}^{-3}$. Cropping under the FP and MN treatments showed negative trends in SOC and TN over 30 years, with average losses ranging from 17 to $74 \mathrm{~kg} \mathrm{ha}^{-1} \mathrm{yr}^{-1}$ and 6 to $16 \mathrm{~kg} \mathrm{ha}^{-1}$ $\mathrm{yr}^{-1}$, respectively. In contrast, the MMR treatment showed positive trends in both soil organic carbon (SOC) and total nitrogen (TN). The SOC and TN increased by $2.6-194 \mathrm{~kg} \mathrm{ha}^{-1} \mathrm{yr}^{-1}$ and 6-14 $\mathrm{kg} \mathrm{ha}^{-1} \mathrm{yr}^{-1}$, respectively. According to the simulation results it can be concluded that the MMR treatment can improve the water productivity of smallholder maize systems in the semi-arid areas of Zimbabwe under nutrient-depleted soil conditions and can also contribute to the building up of SOC and TN.
\end{abstract}

(c) 2013 Elsevier Ltd. All rights reserved.

\section{Introduction}

Crop water productivity (WP) is generally defined as the ratio of crop yield to actual evapotranspiration (Cai and Rosegrant, 2003; Liu et al., 2008), and can be improved by producing the same output with less water or by increasing output with the same amount of water (Mustafa et al., 2008). Grain water productivity of cereal crops in sub-Saharan Africa currently ranges from 0.04 to $0.1 \mathrm{~kg} \mathrm{~m}^{-3}$ while the potential is more than $1.0 \mathrm{~kg} \mathrm{~m}^{-3}$ (Rockström et al., 2003). Similarly, rain-fed crop production systems in the semi-arid tropics of Zimbabwe are also characterized by low WP despite research and extension efforts to develop and popularize improved genetic material and management practices (Ahmed et al., 1997). Low WP is partly attributed to inherent low soil fertility, which is further exacerbated by continuous cropping without addition of adequate organic and inorganic fertilizers due to unavailability and high costs (Nzuma et al., 1998; Mugwe et al., 2004). The challenge is to improve soil fertility and water

\footnotetext{
* Corresponding author.

E-mail address: p.masikate@cgiar.org (P. Masikati).
}

management in order to increase the productive green water (plant transpiration) use under rain-fed cropping systems (Rockström et al., 2003). Sandy soils are predominant in the smallholder farming systems of Zimbabwe, and these soils are inherently infertile, poorly buffered and contain small amounts of soil organic matter (SOM) (Zingore, 2006). Low SOM is also attributed to high turnover rates caused by the high tropical temperatures and the poor protection offered by sandy soils to microbial attack (Mapfumo and Giller, 2001). Therefore, there is a need to regularly apply external organic inputs.

Alternative sources of soil amendments need to be sought in smallholder farming systems, where soil fertility needs to be rebuilt and where high cost and low supply quantities of inorganic fertilizers limit their application (Omotayo and Chukukwa, 2009). In Zimbabwe, leguminous forage crops such as Lablab purpureus, Mucuna pruriens, Medicago sativa, and Cajanus cajan have been introduced as green manure or cover crops to commercial and communal farmers mostly in the sub-humid areas, where cereal crops productivity was improved through provision of alternative low-cost organic fertilizers (Maasdorp and Titterton, 1997; Ngongoni et al., 2007). Grain legumes are also known to improve 
soil fertility, but farmers only grow them on small areas because of their preference for cereal staples, lack of high quality seeds, disease constraints and lack of output markets (Ncube et al., 2008). In contrast, forage legumes, such as mucuna, can be grown on fallow land, seed can be reproduced, and biomass can be used as green manure to improve soil fertility or as livestock feed. Mucuna production has been successfully tested under smallholder conditions on exhausted sandy soils where biomass yield ranged from 2 to $6 \mathrm{tha}^{-1}$ and up to $10 \mathrm{tha}^{-1}$ without and with P fertilizer application, respectively (Waddington et al., 2004). Maize grain yield increases of more than $64 \%$ have been measured in Zimbabwe after application of mucuna as green manure, where nitrogen $(\mathrm{N})$ contribution from mucuna biomass ranged from 101 to $348 \mathrm{~kg} \mathrm{~N} \mathrm{ha}^{-1}$ (Whitbread et al., 2004). In Malawi, maize following mucuna yielded about $1.5 \mathrm{tha}^{-1}$, while maize under the recommended fertilizer application yielded $2.3 \mathrm{tha}^{-1}$ and $0.8 \mathrm{tha}^{-1}$ on unfertilized plots (Sakala et al., 2003). Mucuna is a vigorous twining crop that can grow on sandy soils with low available phosphorus (P) (Cook et al., 2005), and can suppress weeds such as Imperata cylindrical and Striga, which are some of the most problematic weeds in the depleted sandy soils in most smallholder farming systems (Weber, 1996; Ikie et al., 2006). Natural pasture provides the basic feed for ruminant animal production (Woyengo et al., 2004) in these systems and grass biomass and quality is low during the dry season with protein content dropping from 120 to $160 \mathrm{~g}$ crude protein (CP) $\mathrm{kg}^{-1}$ dry matter (DM) in the growing season to as low as 10-20 CP kg-1 DM in the dry season (Baloyi et al., 1997; Maasdorp and Titterton, 1997; Mpairwe, 2005). This causes livestock dry season feed levels to be critically low in terms of quantity and quality consequently affecting both the growth and reproductive performance of the livestock. Mucuna can be used as forage, silage, and hay, and can produce high amounts of biomass depending on rainfall even in soils with low available P (Cook et al., 2005), which makes it an appropriate crop for mixed crop-livestock smallholder farming systems.

From the above maize-mucuna rotations appear to be a promising technology to improve soil fertility, and crop and livestock productivity. However, a clear understanding of the attainable productivity of such systems is lacking, and to what extent these can satisfy both crop (soil improvement) and livestock (feed) needs can be satisfied remains unknown. To quantify biomass production and WP of different cropping systems and their long-term impacts on soil fertility experimentally is extremely cost and time consuming. A preferred approach is to use well-proven crop simulation models, hence a modeling approach was taken in this study. The model used was the Agriculture Production Systems sIMulator (APSIM). APSIM is a modular modeling framework that can be used to simulate complex climate-soil-vegetation management systems (McCown et al., 1996; Keating et al., 2003). It has been tested in Africa to evaluate crop production under a wide range of management systems and conditions. In the Sahel zone, for example, Akponikpe et al. (2010) investigated millet response to $\mathrm{N}$ with a view to establish recommendations for $\mathrm{N}$ application better adapted to smallholder farmers. Delve et al. (2009) evaluated P response in annual crops in eastern and western Kenya. Ncube et al. (2008) assessed the impact of grain legumes on cereal crops grown in rotation in nutrient-deficient systems in Zimbabwe. Shamudzarira (2003) evaluated the potential of mucuna green manure technologies to improve soil fertility and crop production in southern Africa, while Robertson et al. (2005) evaluated the response of maize to previous mucuna and $\mathrm{N}$ application in Malawi.

Published research work on field experiments of maize-mucuna rotations in Zimbabwe is mostly on a short-term basis, and these cropping systems have mainly been tested for crop improvement especially in cereal grain production. Long-term effects of maize-mucuna rotations on soil fertility and attainable production of food and feed have not been tested under smallholder farming systems in the semi-arid areas of Zimbabwe. However the livestock feed issues are not dealt with in this paper. The APSIM model was used in this study to evaluate the long-term effects of maizemucuna rotations (i) on biomass production, grain yield, and water productivity of maize and mucuna, (ii) on dynamics of soil organic carbon and total nitrogen, and (iii) to investigate the degree of water and nitrogen stress in maize-mucuna rotation systems across seasons.

\section{Materials and methods}

\subsection{APSIM model description and parameterization}

The predictive performance of APSIM for maize grain and stover yield and mucuna biomass was tested under three fertility treatments namely the control (no fertility amendments), microdose $\left(17 \mathrm{~kg} \mathrm{~N} \mathrm{ha}^{-1}\right.$ ) (Twomlow et al., 2008) and recommended $\left(52 \mathrm{~kg} \mathrm{~N} \mathrm{ha}^{-1}\right)$ fertilizer application on two soil types (Masikati, 2011). The field experiments used to evaluate the model were carried out at the International Research Institute in the Semi-Arid Tropics (ICRISAT), Matopos Research Station $\left(20^{\circ} 25^{\prime}\right.$ south and $28^{\circ} 24^{\prime}$ east) during the cropping season $2008-2009$. With regards to mucuna, the model was evaluated only for the recommended (RC) treatment, as mucuna did not respond to the different $P$ fertilizer application rates under the microdose (MD) and the recommended (RC) treatments (Masikati, 2011). This could be attributed to soil P levels which were $>10 \mathrm{ppm}$ and considered to be optimal for mucuna production (Reuter et al., 1997). The model satisfactorily simulated these management practice differences within experimental error (Fig. 1a and b). The root mean square error (RMSE) for maize grain, maize stover and mucuna biomass across treatments was 404, 599 and $304 \mathrm{~kg} \mathrm{ha}^{-1}$, respectively.
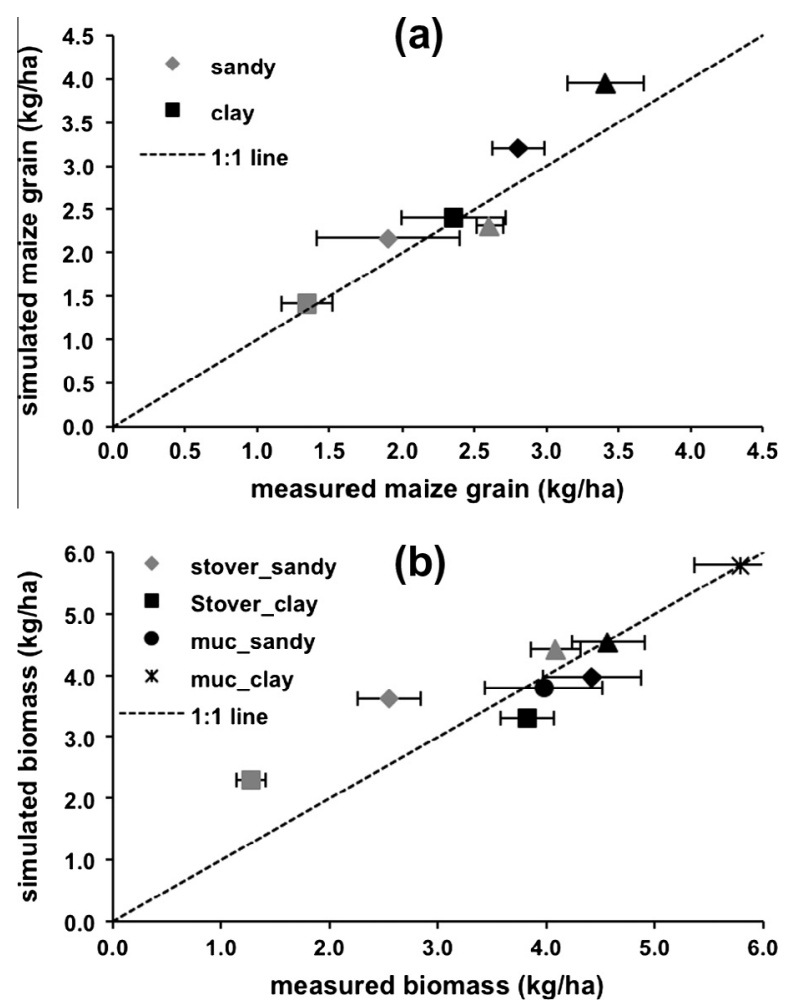

Fig. 1. (a and b) Simulated and observed maize grain yield (a) and maize stover and mucuna biomass (b) on clay and sandy soils. Maize grain yield under the FP, MD and $\mathrm{RC}$ treatments are shown by the different shapes as square, diamond and triangle, respectively. 
After evaluating the APSIM model regarding its predictive performance for maize grain and stover and mucuna biomass yield (Masikati, 2011), the model was used to evaluate the long-term effects of different crop production systems on water productivity (WP), total soil nitrogen (TN) and soil organic carbon (SOC). Although the model was not evaluated for soil $\mathrm{N}$ and $\mathrm{OC}$ in the current study, it has capabilities to simulate soil $\mathrm{N}$ and $\mathrm{OC}$ dynamics (Probert and Dimes, 2004) and has been used to evaluate soil $\mathrm{N}$ and OC dynamics in similar environments. Chivenge et al. (2004) used the model to simulate maize response to manure inputs in the dry and wet areas of Zimbabwe, while Ncube et al. (2008) used the model to assess productivity and residual benefits of grain legumes to sorghum in the dry areas of Zimbabwe.

To simulate the cases in this study, the APSIM-maize, APSIMmucuna, APSIM-weed (Robertson et al., 2005), SOILN2 and SOILWAT2 modules (Probert et al., 1998) were linked within the APSIM version 6.1. The maize and mucuna cultivars used in the experiments have set parameters in APSIM. The maize cultivar SC401 is an early maturing hybrid from Zimbabwe and has been extensively used by a number of researchers to simulate maize production in Africa (Probert, 2007; Delve et al., 2009). The mucuna_gen in APSIM developed by Robertson et al. (2005) is a typical cultivar, which is grown under smallholder conditions in southern Africa. Based on model testing Robertson et al. (2005) state that APSIMmucuna can be used with high confidence in this part of Africa.

\subsection{Climate data and crop management}

Simulations were run for 30 years from 1978 to 2008 using daily weather data (precipitation, minimum and maximum temperatures, and solar radiation) recorded by the national weather bureau of the Matopos Research Station. Sandy soils, which are predominant in the smallholder farming systems of Zimbabwe, were used for the simulations (Table 1). A short duration maize variety SC401 and mucuna were planted at 3.5 and 10 plants $\mathrm{m}^{-2}$, respectively, and the sowing window was from November to December each year. Soil moisture conditions for sowing were set to $20 \mathrm{~mm}$ cumulative rainfall over 5 days.

Simulations were done for crop-livestock mixed farming systems in semi-arid areas of Zimbabwe. In these systems, crop and livestock complement and compete with each other especially for resources such as crop residues. Mostly farmers opt to use crop residues to feed livestock, and this has been a stumbling block for promoting conservation agriculture (Probert, 2007). Average cattle holding per household in smallholder farming systems in SAT of Zimbabwe is approximately 6 animals with average adult live weight of approximately $300 \mathrm{~kg}$ (Masikati, 2011). This study aims to determine the effects of maize residue removal rates as determined by livestock feed requirements during the dry season on crop production and potential feed supply. To evaluate the robustness of the different crop production systems, the amounts of residues removed yearly were estimated to be equivalent to the

\section{Table 1}

Initial soil organic carbon $(\mathrm{OC})$ and nitrate-nitrogen $\left(\mathrm{NO}_{3}-\mathrm{N}\right)$ of soil samples collected from experimental sites, in December 2008 and soil physical parameters.

\begin{tabular}{lllllll}
\hline \multirow{2}{*}{ Parameter } & \multicolumn{7}{l}{ Soil layer $(\mathrm{cm})$} & & & \\
\cline { 2 - 7 } & $0-15$ & $15-30$ & $30-45$ & $45-60$ & $60-75$ & $75-100$ \\
\hline OC $(\%)$ & 0.52 & 0.43 & 0.35 & 0.30 & 0.21 & 0.21 \\
$\mathrm{NO}_{3}-\mathrm{N}(\mathrm{ppm})$ & 3.08 & 2.16 & 2.30 & 2.21 & 2.55 & 1.07 \\
Airdry $(\mathrm{mm} / \mathrm{mm})$ & 0.03 & 0.07 & 0.09 & 0.09 & 0.09 & 0.09 \\
LL $15(\mathrm{~mm} / \mathrm{mm})$ & 0.06 & 0.10 & 0.13 & 0.13 & 0.18 & 0.22 \\
DUL $(\mathrm{mm} / \mathrm{mm})$ & 0.16 & 0.18 & 0.19 & 0.20 & 0.22 & 0.24 \\
SAT $(\mathrm{mm} / \mathrm{mm})$ & 0.41 & 0.41 & 0.41 & 0.37 & 0.36 & 0.34 \\
Bulk density $\left(\mathrm{g} \mathrm{cm}^{-3}\right)$ & 1.43 & 1.42 & 1.42 & 1.55 & 1.55 & 1.61 \\
\hline
\end{tabular}

amount required to meet $100 \%$ of daily dry matter (DM) requirements during 3 months of critical feed shortages each year. Daily DM requirements were calculated as 3\% of liveweight (Table 2). The average liveweight of a mature cow measured on-farm was $300 \mathrm{~kg}$. On average land holding in these systems is 4 ha and of these about 1 ha is left as weedy fallow annually.

\subsubsection{Scenario 1 - farmer practice (FP)}

This scenario was set up to simulate the conventional farming practices of smallholder farmers in the semi-arid tropics of Zimbabwe. No soil fertility amendments were added. Weeding was carried out twice at 25 and 50 days after sowing (DAS). Crop residues in this scenario were removed according to feed requirements at harvest to simulate cut and carry systems, where residues are collected and stored and used as feed during the dry season.

\subsubsection{Scenario 2 - manure application (MN)}

Livestock manure, especially from cattle, is one of the most available but most under-utilized organic soil amendments on smallholder farms. The number of animals determines availability of manure, while field application depends mainly on labor availability and fertility status of the field. In this scenario, manure was applied 30 days before the start of the sowing window, to simulate what farmers practice as they carry and apply manure to the fields before the onset of the rainy season. Manure production was estimated using a dry weight production of $3.3 \mathrm{~kg}$ of dung day ${ }^{-1}$ Tropical Livestock Unit (TLU) ${ }^{-1}$ for cattle (Haileslassie et al., 2009), and the application rate was determined by the total size of cropland. This resulted in application rate of $1906 \mathrm{~kg}$ dry matter $\mathrm{ha}^{-1}$. Weeding and removal of crop residues was done as for the FP scenario.

\subsubsection{Scenario - 3 maize-mucuna rotation and manure (MMR)}

In this scenario, maize was grown in rotation with mucuna. Land holding in the dry areas of Zimbabwe is on average 4 ha per household and 1 ha is left as fallow due input shortages or to rest the fields. This allows farmers to have a crop of maize and mucuna each year, hence the simulations were set out to have maize and mucuna yield every year. To evaluate the full benefits of this technology on crop production and soil fertility, the rotation was combined with manure using the same application rates as for the MN scenario. Weeding and removal of crop residues was done as for the FP scenario.

\subsection{Estimating crop water productivity}

To quantify evapotranspiration (ET), the APSIM model uses the SOILWAT2 module. This module uses a multi-layer, cascading approach for the water balance with run-off estimated using the United States Department of Agriculture (USDA) run-off curve number (Probert, 2007). The partitioning of rainfall between infiltration and runoff is determined primarily by the soil curve number (cn2-bare). The model also simulates the effects of surface residues and crop cover on modifying runoff and reducing potential soil evaporation. Soil evaporation is determined by the first stage (U)

Table 2

Cattle dry matter requirements.

\begin{tabular}{ll}
\hline Average cattle holding $^{\mathrm{a}}$ & 6 heads \\
Average live weight $^{\mathrm{a}}$ & $300 \mathrm{~kg}$ \\
Approximate daily dry matter intake $^{\mathrm{b}}$ & $3 \%$ of live weight \\
Critical feed shortage period & September-November ( $\sim 90$ days $)$ \\
\hline a ICRISAT survey (2008). & \\
b FAO (2002). &
\end{tabular}


and second stage (CONA) evaporation. Evapotranspiration was calculated as:

ET $=$ incrop precipitation $-($ runoff + drainage $)$

Water productivity for mucuna biomass was calculated by dividing above-ground dry matter $\left(\mathrm{kg} \mathrm{ha}^{-1}\right)$ by ET. A similar approach was used to calculate maize grain water productivity $\left(\mathrm{WP}_{\text {grain }}\right)$ calculated as grain yield divided by ET.

\subsection{Soil organic carbon and total nitrogen}

The change in SOC and TN under the different treatments was calculated as the rate of change in these variables per year $\left(\mathrm{kg} \mathrm{ha}^{-1}\right.$ year $\left.^{-1}\right)$ as:

Change in $\mathrm{TN}=\left(\mathrm{TN}_{\text {final }}-\mathrm{TN}_{\text {initial }}\right) /($ Number of simulated years $)$

Change in $\mathrm{SOC}=\left(\mathrm{SOC}_{\text {final }}-\mathrm{SOC}_{\text {initial }}\right) /($ Number of simulated years $)$

where $\mathrm{TN}_{\text {final }}$ and $\mathrm{SOC}_{\text {final }}$ are $\mathrm{TN}$ and SOC at the end of the 30-year simulation period, and $\mathrm{TN}_{\text {initial }}$ and $\mathrm{SOC}_{\text {intial }}$ are TN and SOC at the beginning of the simulation period.

For analysis, the top $30 \mathrm{~cm}$ of the soil profile was used to evaluate the effects of the different treatments on SOC. The top $30 \mathrm{~cm}$ were selected, as user-defined tillage depth in the model was $18 \mathrm{~cm}$, which simulates the on-farm plough layer depth (Masikati, 2006). Total $\mathrm{N}$ in the whole soil profile $(0-100 \mathrm{~cm})$ was considered for analysis, as $\mathrm{N}$ is a mobile nutrient.

\section{Results}

\subsection{Maize grain and stover and mucuna biomass yield}

The simulations show inter-annual grain yield variability across all treatments. The highest variability was in the MMR treatment (Fig. 2). In the FP treatment, inter-annual variability of grain yield ranged from less than 0.4 to over $1.2 \mathrm{tha}^{-1}$ while under the MN treatment it ranged from less than 0.4 to slightly over $1.4 \mathrm{tha}^{-1}$. The MMR treatment increased substantially the inter-annual grain yield variability as compared to the other two treatments. In the MMR treatment, grain yield ranged from about $0.8-4.4 \mathrm{tha}^{-1}$, here, grain yield variability was higher within the 25 and 75 percentile. Although there were differences in the highest simulated grain yields, the lowest grain yields were all similar and below $0.7 \mathrm{tha}^{-1}$ across all treatments. The highest grain yields under

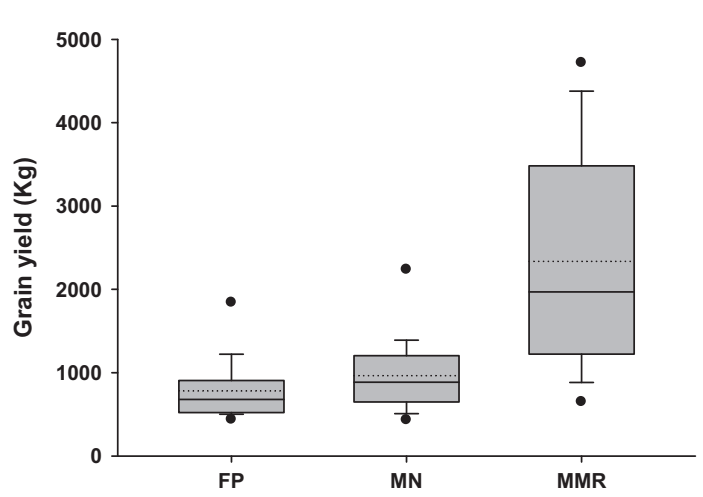

Fig. 2. Simulated effects of soil fertility management on maize grain yield. The boxand-whisker diagrams include: (dotted and solid lines) mean and the median values respectively; (cross bars) maximum and minimum values; (circles) extreme values. $\mathrm{FP}=$ farmer practice, $\mathrm{MN}=$ manure, $\mathrm{MMR}=$ maize-mucuna rotation . the MMR treatment were more than threefold that for the FP and MN treatments. In $75 \%$ of the simulated years, grain yield in the MMR treatment was more than $1 \mathrm{t} \mathrm{ha}^{-1}$, while that in the FP and MN treatments was below 0.5 and $0.6 \mathrm{t} \mathrm{ha}^{-1}$, respectively. Generally, the MMR treatment increased grain yields substantially as compared to the FP and MN treatments.

Maize stover yields across the three treatments also showed inter-annual variability over the simulation period (Fig. 3). Stover yield variability showed a similar pattern to that of maize grain yield where highest variability was in the MMR treatment. However, the lowest yields were not similar across treatments. Lowest stover yields were 0.6 and $0.7 \mathrm{t} \mathrm{ha}^{-1}$ in the FP and MN treatments, respectively, while in the MMR treatment, the lowest stover yields were above $2.0 \mathrm{tha}^{-1}$. The highest stover yields in the FP treatment were $2.3 \mathrm{t} \mathrm{ha}^{-1}$, while those in the MN and MMR treatments were, 2.5 and $6.7 \mathrm{t} \mathrm{ha}^{-1}$, respectively. Generally, the MMR treatment substantially increased stover yields, in $75 \%$ of the simulated years, stover yield under the MMR treatment was more than $3 \mathrm{tha}^{-1}$, while that under the FP treatment was below $1 \mathrm{tha}^{-1}$. There was also inter-annual variability in the mucuna biomass yield (Fig. 3) where lowest biomass yield was $1.1 \mathrm{tha}^{-1}$ and highest was $6.1 \mathrm{t} \mathrm{ha}^{-1}$.

\subsection{Maize grain water productivity}

Maize grain water productivity ( $\left.\mathrm{WP}_{\text {grain }}\right)$ was substantially higher in the MMR treatment compared to the FP and MN treatments (Fig. 4). The FP treatment had the lowest $\mathrm{WP}_{\text {grain. }}$ Grainwater productivity varied over the 30 -year simulation period, with values ranging from less than 2 to more than $1.0 \mathrm{~kg} \mathrm{~m}^{-3}$ across treatments. In the MMR treatment, $\mathrm{WP}_{\text {grain }}$ could exceed $0.60 \mathrm{~kg} \mathrm{~m}^{-3}$ in $50 \%$ of the simulated years while it was about 0.32 and $0.40 \mathrm{~kg} \mathrm{~m}^{-3}$ in the FP and MN treatments, respectively. The results also show that it is possible to attain higher $\mathrm{WP}_{\text {grain }}$ values in some years. For example, in $30 \%$ of the simulated years, $W P_{\text {grain }}$ could exceed $1.0 \mathrm{~kg} \mathrm{~m}^{-3}$ in the MMR treatment. The highest attainable $\mathrm{WP}_{\text {grain }}$ value in the $\mathrm{FP}$ treatment was about $0.80 \mathrm{~kg} \mathrm{~m}^{-3}$, while in the MN and MMR treatments were 0.90 and $1.4 \mathrm{~kg} \mathrm{~m}^{-3}$, respectively.

\subsection{Soil nitrate nitrogen}

Soil nitrate nitrogen $\left(\mathrm{NO}_{3}-\mathrm{N}\right)$ in the soil profile averaged for each month across the simulated 30 years was substantially influenced by the different fertility treatments (Fig. 5). It was lowest under the FP treatment and highest under the MMR treatment. There

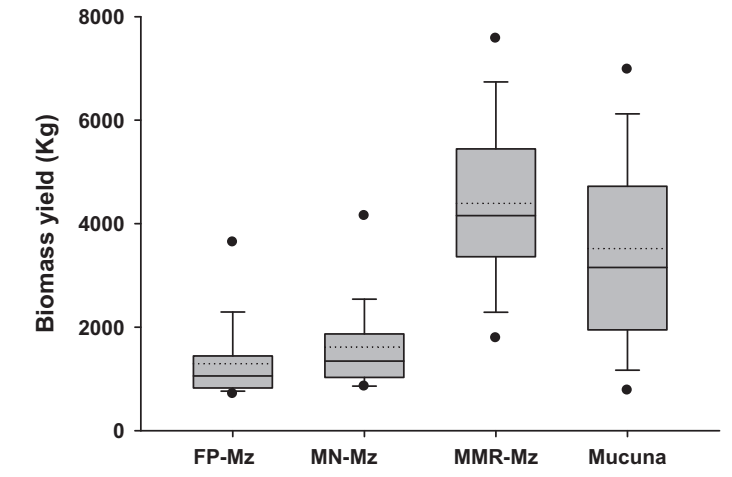

Fig. 3. Simulated effects of soil fertility management on maize stover and mucuna biomass yield. The box-and-whisker diagrams include: (dotted and solid lines) mean and the median values respectively; (cross bars) maximum and minimum values; (circles) extreme values. $\mathrm{FP}=$ farmer practice, $\mathrm{MN}=$ manure, $\mathrm{MMR}=$ maizemucuna rotation. 


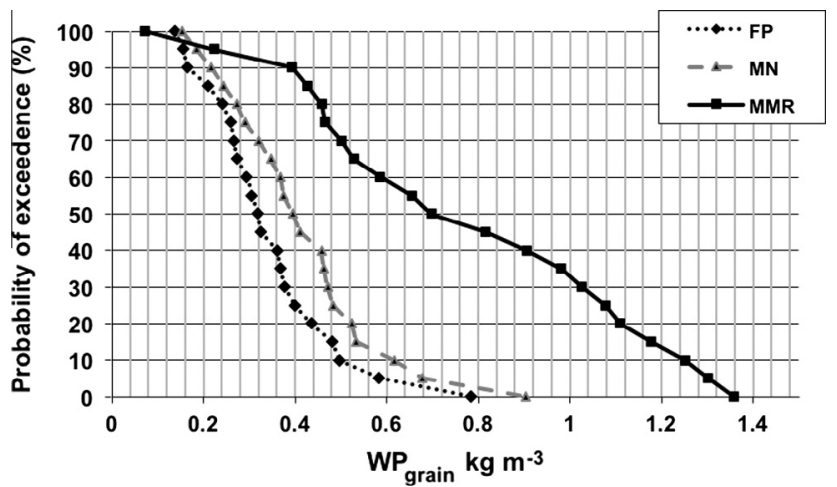

Fig. 4. Effects of soil fertility management on maize grain water productivity $\left(\mathrm{WP}_{\text {grain }}\right)$ simulated over a period of 30 years. $\mathrm{FP}=$ farmer practice; $\mathrm{MN}=$ manure; $\mathrm{MMR}=$ maize-mucuna rotation.

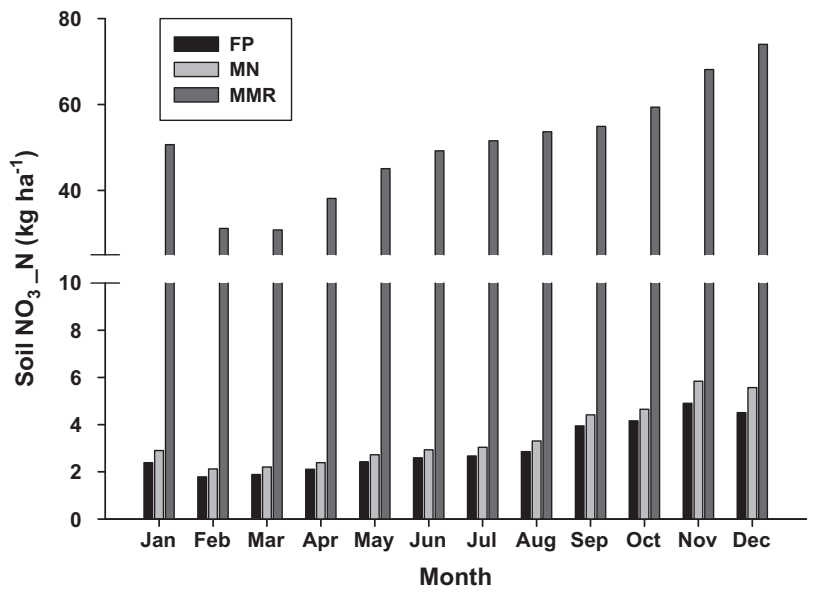

Fig. 5. Soil nitrate nitrogen $\left(\mathrm{NO}_{3}-\mathrm{N}\right)$ averaged for each month for the simulated 30 years for, $\mathrm{MN}=$ manure, $\mathrm{MMR}=$ maize- mucuna rotation.

were minor differences between the FP and MN treatments although soil $\mathrm{NO}_{3}-\mathrm{N}$ in the $\mathrm{MN}$ treatment was slightly higher than that of the FP treatment from October to November. Simulated soil $\mathrm{NO}_{3}-\mathrm{N}$ values were highest in November and December across all treatments. The highest soil $\mathrm{NO}_{3}-\mathrm{N}$ in the $\mathrm{FP}$ treatment was $4.9 \mathrm{~kg} \mathrm{ha}^{-1}$, while in the MN treatment it was $6.0 \mathrm{~kg} \mathrm{ha}^{-1}$ and under MMR treatment $78.0 \mathrm{~kg} \mathrm{ha}^{-1}$. A 13- to more than 15 -fold soil $\mathrm{NO}_{3}-\mathrm{N}$ was simulated for the MMR treatment compared to the FP and $\mathrm{MN}$ treatments. High $\mathrm{NO}_{3}-\mathrm{N}$ under the MMR treatment could explain the high grain and stover yields as compared to the other 2 treatments.

\subsubsection{Dynamics of soil total nitrogen and soil organic carbon}

There were pronounced positive and negative trends in TN over the simulated 30 years for all treatments (Fig. 6). The FP and MN treatments showed a substantial decrease in TN over time. A substantial decrease was exhibited, where initial TN was $4.1 \mathrm{tha}^{-1}$ and final TN was $3.7 \mathrm{tha}^{-1}$ in the FP treatment and $3.8 \mathrm{t} \mathrm{ha}^{-1}$ in the MN treatment. Under the MMR treatment there was a marked increase from 4.1 to $4.4 \mathrm{t} \mathrm{ha}^{-1}$. Soil organic carbon (SOC) followed a pattern almost similar to that of total nitrogen, as it was also influenced by treatment over the simulated 30 years in the top $30 \mathrm{~cm}$ of the soil profile (Fig. 7). There was a substantial decrease, where initial SOC was $21.0 \mathrm{t} \mathrm{ha}^{-1}$ and final $19.8 \mathrm{tha}^{-1}$ under the FP and $20.7 \mathrm{t} \mathrm{ha}^{-1}$ under the MN treatments, respectively. In the MMR treatment, there was a marked increase in SOC from 21.0 to about

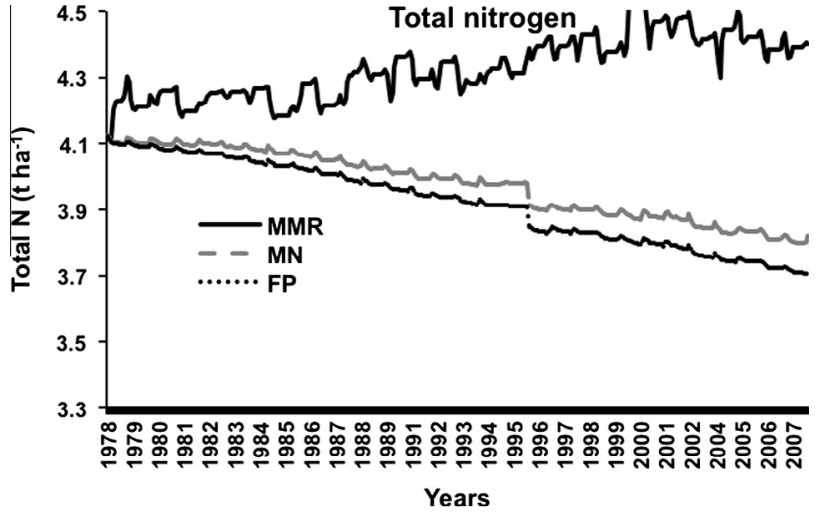

Fig. 6. Dynamics of soil total nitrogen $(\mathrm{TN})$ in the soil profile $(0-70 \mathrm{~cm})$ simulated over 30 years under three treatments. $\mathrm{FP}=$ farmer practice, $\mathrm{MN}=$ manure $\mathrm{MMR}=$ maize-mucuna rotation

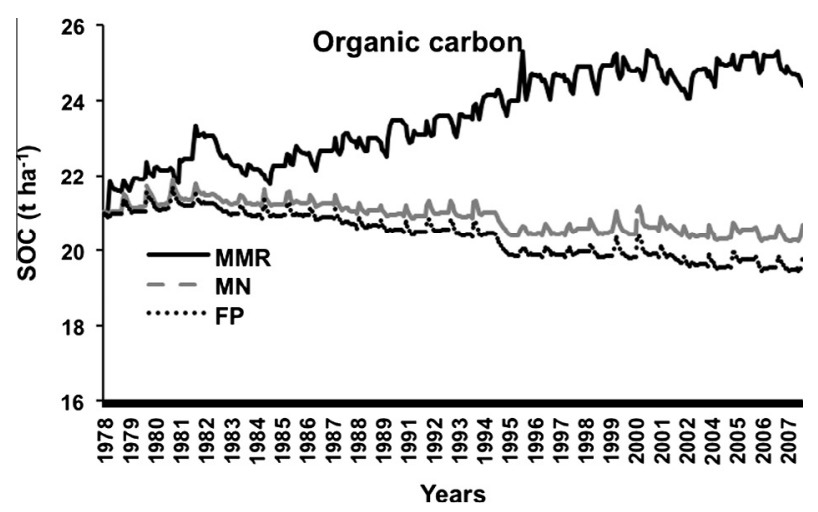

Fig. 7. Dynamics of soil organic carbon (SOC) in the top $30 \mathrm{~cm}$ of the soil profile simulated over 30 years under three fertility treatments. $\mathrm{FP}=$ farmer practice, $\mathrm{MN}=$ manure, $\mathrm{MMR}=$ maize- mucuna rotation.

$24.7 \mathrm{t}^{\mathrm{h}} \mathrm{a}^{-1}$. Generally, the MMR treatment improved TN and SOC substantially over time.

Annual rates of increase or decrease in SOC and TN varied between the different treatments (Table 3). Losses under FP were the highest compared to the other two treatments. Losses of $50.7 \mathrm{~kg} \mathrm{SOC} \mathrm{ha}{ }^{-1} \mathrm{yr}^{-1}$ were simulated. Under the MN treatment,

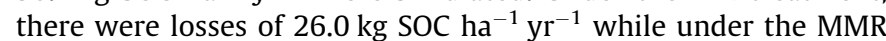
treatment, SOC increased by $110.0 \mathrm{~kg} \mathrm{ha}^{-1} \mathrm{yr}^{-1}$. Total soil $\mathrm{N}$ under the different treatments also showed both negative and positive balances over the simulation period. Generally, there were negative trends across all treatments except under the MMR treatment. There was a positive $\mathrm{N}$ balance under the MMR treatment with mean annual gains of $6.1 \mathrm{~kg} \mathrm{~N} \mathrm{ha}^{-1} \mathrm{yr}^{-1}$, respectively.

\subsubsection{Nitrogen and water stress factors}

Both rainfall and nitrogen $(\mathrm{N})$ play an important role in crop production. Average annual rainfall was $534 \mathrm{~mm}$ across the

Table 3

Trends in soil organic carbon (SOC) and total soil nitrogen (TN) under three treatments. Soil organic carbon in top $30 \mathrm{~cm}$ of the soil profile and total nitrogen in soil profile to $70 \mathrm{~cm}$ depth. $\mathrm{FP}=$ farmer practice; $\mathrm{MN}=$ manure; $\mathrm{MMR}=$ maizemucuna rotation.

\begin{tabular}{llc}
\hline Treatment & SOC $\left(\mathrm{kg} \mathrm{ha}^{-1} \mathrm{yr}^{-1}\right)$ & $\mathrm{TN}\left(\mathrm{kg} \mathrm{ha}^{-1} \mathrm{yr}^{-1}\right)$ \\
\hline FP & -50.7 & -13.5 \\
MN & -26.0 & -10.5 \\
MMR & 110.0 & 6.1 \\
\hline
\end{tabular}




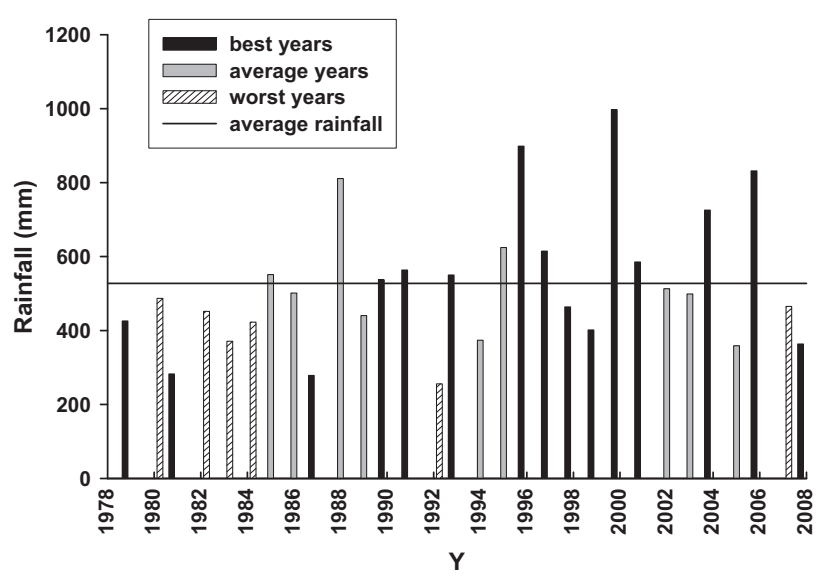

Fig. 8. Annual rainfall and year performance indicated by APSIM for maize grain yield simulated from 1978 to 2008 under different treatments. Years were categorized according to yearly performance of the MMR treatment as indicated by APSIM in the maize yield simulation from 1978 to 2008 and randomly selected across the treatments. Selected worst years were 1980, 1982, and 1992, normal years were 1986, 1994 and 2002, and best years were 1996, 2000 and 2004.

simulated 30 years; highest rainfall of $1000 \mathrm{~mm}$ was recorded in 2000 and lowest in 1992 of about $250 \mathrm{~mm}$ (Fig. 8). Years with high rainfall did not always coincide with high yields. For example, in the wet years of 1985 and 1988, where annual rainfall was 624 and $811 \mathrm{~mm}$, respectively, grain yields were slightly above $1 \mathrm{t} \mathrm{ha}^{-1}$ under the MMR treatment. There were also years with belowaverage annual rainfall which, had very high yields, e.g., 1981 and 1999 where annual rainfall was 283 and $402 \mathrm{~mm}$, respectively, and average grain yield was above $3 \mathrm{tha}^{-1}$ under the MMR treatment. To determine the effects of rainfall and $\mathrm{N}$ on crop production under the different treatments, an analysis of soil $\mathrm{N}$ and water stress factors during maize growth periods was done for the worst years (Fig. 9a and b), average (Fig. 9c and d) and best years (Fig. 9e and f).

The simulated soil $\mathrm{N}$ and soil water (SW) stress factors predicted for the worst years showed that crops under the FP and MN treatments generally experienced slight to severe $\mathrm{N}$ stresses from approximately 10 days after sowing (DAS) until crop maturity. (Fig. 9a and b). In the worst years, N stress below 0.5 was experienced by crops under the FP and MN treatments from approximately 46 DAS. There was no critical $\mathrm{N}$ stress under the MMR treatment in the worst years. Soil water stress below 0.5 was experienced by crops under the MMR treatment at approximately 60 DAS. No SW stress was simulated for crops under the $\mathrm{FP}$ and MN treatments. During the average years, $\mathrm{N}$ stresses below 0.5 were experienced by crops under the FP and MN treatments at approximately 49 DAS (Fig. 9c and d). No N stress was simulated under the MMR treatment. No SW stress was experienced by crops under the FP and MN treatments but there was SW stress under the MMR treatment that was experienced around 84 DAS. Effects here could not be critical for grain production as stress affected crops almost at maturity, which is a different case under the worst years. In the worst years water stress is experienced during flowering which substantially affects grain production. In the best years, simulations showed $\mathrm{N}$ stress under the FP and MN treatments while under the MMR treatment no $\mathrm{N}$ stress below 0.5 was experienced (Fig. 8e and f). Only minimal SW stress was experienced by crops under the MMR treatment. Generally, N stress was below 0.5 and there was no SW stress under the FP and MN treatments. In the best years, no critical N and SW stress was experienced by crops under the MMR treatment. In the simulated 30 years, 20,30 and $50 \%$ of the years were worst, average and best respectively.

\section{Discussion}

\subsection{Maize and mucuna biomass yield}

In the rain-fed semi-arid tropics of Zimbabwe, the agro-ecosystems are characterized by erratic rainfall patterns during the growing season. Low water holding capacity of the predominant sandy soils coupled with low soil organic matter and high evaporation further contribute to soil moisture limitation during this period. Crop production is monoculture and cereal based with minimal application of soil fertility amendments. The simulated maize grain yields showed variations across seasons, treatments. There were pronounced differences in maize grain yield across treatments, where yields were low under the FP treatment, showing the negative effects of non-application of soil amendments. Low maize grain yield under the conventional farmer practice have been observed in an on-farm experiment (12 years) in the sub-humid areas of Zimbabwe (Waddington et al., 2004). Maize yield with manure application was lower than that in the maize-mucuna rotation. This can be attributed to the low manure quantities applied ( $1.9 \mathrm{t}$ dry matter $(\mathrm{DM}) \mathrm{ha}^{-1}$ ) while recommended is $10 \mathrm{t} \mathrm{DM} \mathrm{ha}^{-1}$ (Mugwira and Shumba, 1986). Under the MMR treatment, simulated yields were substantially increased, but there was also high inter-annual variability. Lowest maize grain yields were below $0.5 \mathrm{tha}^{-1}$, and highest yields were above $4 \mathrm{tha}^{-1}$. For maize stover, the lowest yields were about $1.5 \mathrm{tha}^{-1}$, and the highest about $8 \mathrm{t} \mathrm{ha}^{-1}$. Maize stover yields are usually not measured but maize grain yields observed here are comparable to those observed by Sakala et al. (2003) under a maize-mucuna rotation system where maize grain yield was about $3.5 \mathrm{tha}^{-1}$ against $1 \mathrm{tha}^{-1}$ from the continuous unfertilized maize. Yields were improved by a combination of manure and crop residues and nitrogen fixation which, contributed to about $70 \mathrm{~kg} \mathrm{ha}^{-1}$ of soil $\mathrm{NO}_{3}-\mathrm{N}$ at the beginning of the cropping season. The results showed that in smallholder mixed crop-livestock systems, the conventional monoculture cropping with low application of soil fertility amendments can be significantly improved by incorporating forage legumes in rotation with cereal crops. Mucuna was chosen in this study for its drought tolerance, low susceptibility to aphids and potential to improve soil fertility and subsequent crop yield (Nyambati, 2002; Maasdorp et al., 2004) as well as for being a high protein livestock supplementary feed in semi-arid areas in Zimbabwe (Maasdorp and Titterton, 1997). A number of studies done in Africa have shown that mucuna can fix more than $50 \mathrm{~kg} \mathrm{~N} \mathrm{ha}^{-1}$ year $^{-1}$ on a sandy loam soil (Giller, 2001) while maize yields of 3-6 $\mathrm{tha}^{-1}$ were observed under mucuna as green manure with no additional mineral $\mathrm{N}$ fertilizer (Kumwenda and Gilbert, 1998). In this study, the rotation had positive effects on both maize grain and stover yields. Mucuna biomass was also high with an average yield of $3.5 \mathrm{tha}^{-1}$. Mucuna biomass yield of more than $5 \mathrm{tha}^{-1}$ was attained in 6 out of 30 simulated years, which is similar to values reported for smallholder farming systems in sub-humid areas of Zimbabwe (Waddington et al., 2004). The use of forage legumes in rotation with cereal crops has been reported to have beneficial effects not only in the overall grain yield production, but also in the chemical and physical properties of the soil (Nyambati, 2002; Waddington et al., 2004; Álvaro-Fuentes et al., 2009).

\subsubsection{Maize grain water productivity}

Simulations using the APSIM model revealed that in the study area $\mathrm{WP}_{\text {grain }}$ is adversely affected to a great extent by low soil fertility. Interventions that can improve soil fertility are likely to have positive impacts on WP. Attainable $\mathrm{WP}_{\text {grain }}$ of the rain-fed semiarid tropics is $0.9-1.2 \mathrm{~kg} \mathrm{~m}^{-3}$ (Rockström et al., 2003; Cai and Rosegrant, 2003). In this study, average $\mathrm{WP}_{\text {grain }}$ of maize under the MMR treatment was $0.6 \mathrm{~kg} \mathrm{~m}^{-3}$. The highest values ranging 

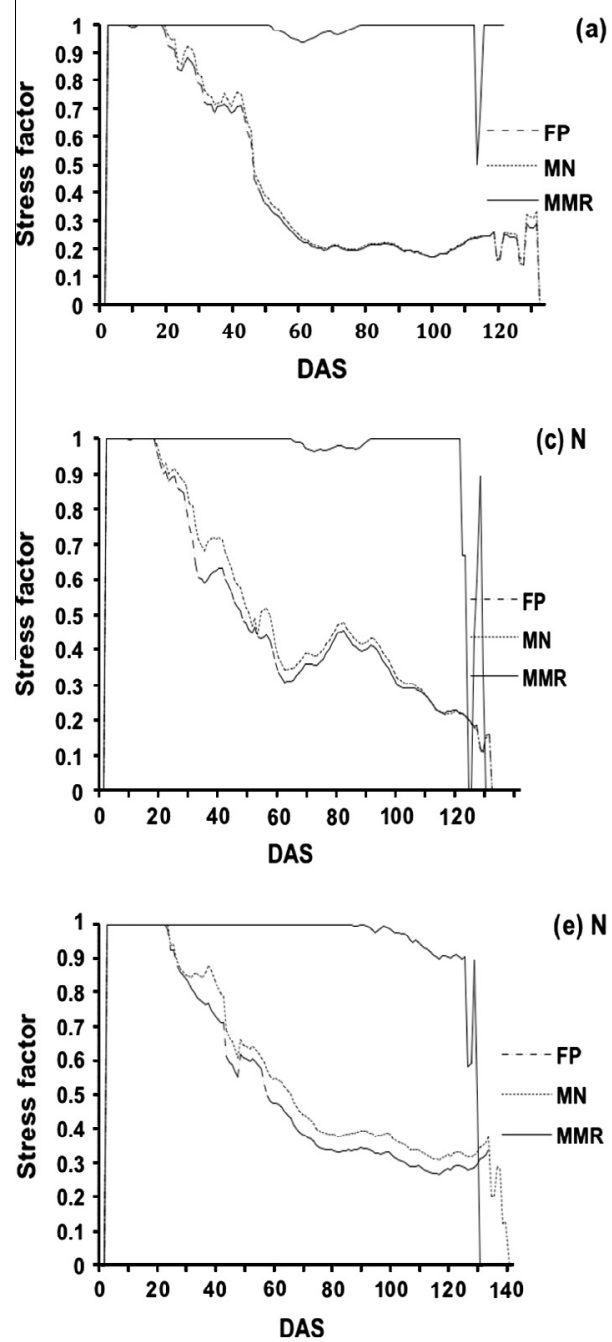

(e) $\mathrm{N}$
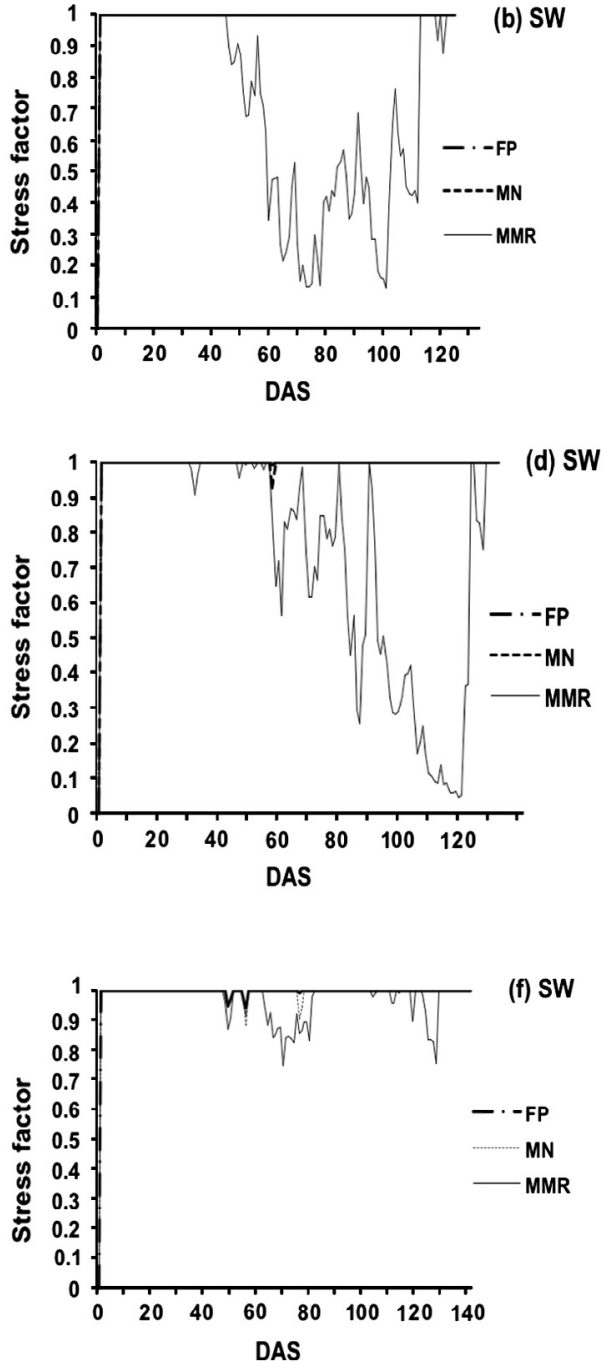

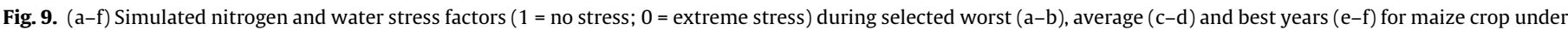
three fertility treatments $\mathrm{FP}=$ farmer practice, $\mathrm{MN}=$ manure, $\mathrm{MMR}=$ maize-mucuna rotation. $\mathrm{N}=$ soil nitrogen, $\mathrm{SW}=$ soil water $\mathrm{DAS}=$ days after sowing.

between 1.0 and $1.2 \mathrm{~kg} \mathrm{~m}^{-3}$ were achieved in only 3 of the simulated 30 years, while $0.9 \mathrm{~kg} \mathrm{~m}^{-3}$ was achieved in $30 \%$ of the years. This shows that there is scope to improve WP on smallholder farms with increases in soil fertility.

An analysis of $\mathrm{N}$ and SW stress factors during maize growth periods was done for the worst, average and best years. Rainfall was a limiting factor in the MMR treatment, while soil $\mathrm{N}$ was a limiting factor in the FP and MN treatments across all year categories. Nitrogen stress below 0.5 was experienced from the floral initiation stage until crop maturity. It can be said that under low fertility conditions in semi-arid areas, maize production is more limited by fertility than by soil water, as crops under the FP and MN treatments did not experience SW stress in any year.

On the other hand, the high soil $\mathrm{NO}_{3}-\mathrm{N}\left(>50 \mathrm{~kg} \mathrm{ha}^{-1}\right)$ in the MMR treatment showed that in this treatment there was no $\mathrm{N}$ stress below 0.5 during all years. However, water was limiting during the worst and average years. Water stress below 0.5 was experienced by crops between the floral initiation and flag leaf stages during the worst years and at the flowering stage during the average years. On average, there was a difference of about 24 days between the onset of water stress during the worst and average years. Water stress experienced by the crops under the MMR treatment led to a reduction in the harvest index (HI). Under the FP treatment, the $\mathrm{HI}$ was $0.34,0.42$ and 0.38 while under the MN treatment it was $0.33,0.42$ and 0.39 during the worst, average and best years, respectively. Under the MMR treatment, it was $0.11,0.24$ and 0.40 during the worst, average and best years, respectively. Higher soil $\mathrm{N}$ increases crop growth and biomass production, which means higher transpiration to produce the biomass, and thus the soil water becomes depleted more quickly. This can result in water stress during grain setting if there is no rainfall event during that period, thus leading to reduced grain numbers. Soil water stress was experienced during the critical period for grain setting (flowering stage). This is also evidenced by the low variability in maize stover and mucuna biomass yield across the years as compared to the variability in grain yield. No soil water stress was experienced during the best years. It is therefore important to note that when soil fertility is improved in these areas, rainfall becomes the limiting factor. Rockström et al. (2003) showed that in current drought-prone agroecosystems, with improved soil management practices there are no agrohydrological limitations to double or even quadruple staple food yields.

\subsubsection{Soil organic carbon and total nitrogen}

The simulation results show that the conventional FP treatment has negative effects on both SOC and TN content over time. Soil organic carbon and TN were substantially decreased mainly because no organic soil amendments were applied. Losses of SOC ranged 
from 17 to $74 \mathrm{~kg} \mathrm{ha}^{-1} \mathrm{yr}^{-1}$, while TN losses ranged from 9 to $16 \mathrm{~kg} \mathrm{ha}^{-1} \mathrm{yr}^{-1}$. For soils that are already impoverished, these are significant losses, which are detrimental to future crop production. The manure treatment also had negative effects on SOC and TN as both quality and quantity of manure available to smallholder farmers are low. Although the recommended annual application of manure ranges from 8 to $10 \mathrm{t}(\mathrm{DM}) \mathrm{ha}^{-1}$ most farmers can only afford to have $3-6 \mathrm{t}(\mathrm{DM})$ year $^{-1}$ but delivery and application to the fields is mainly determined by labor availability (Mapfumo and Giller, 2001). Under the MMR treatment both SOC and TN were substantially increased over the years. Increases of about $110 \mathrm{~kg}$ SOC $\mathrm{ha}^{-1} \mathrm{yr}^{-1}$ are attributed to crop residues and below ground biomass. Benefits could be obtained mainly from crop residues and below ground biomass. However, it is important to note that there is lack of experimental data showing long-term effects of conventional and cereal-legume rotation on SOC and TN dynamics in smallholder farming systems (Zingore, 2006; Probert, 2007). Sanchez et al. (1997) reported N losses of up to $660 \mathrm{~kg} \mathrm{ha}^{-1}$ in a period of about 30 years from an estimated 200 million ha of cultivated land in 37 African countries. In this study, the simulated SOC and TN trends under the FP are very similar to the prevailing situation in smallholder farming systems in the semi-arid tropics of Africa (Sanchez et al., 1997; Waddington et al., 2004; Probert, 2007). Soil organic carbon is the backbone of soil organic matter, which affects soil quality because it is a nutrient reservoir and positively influences soil properties such as cation exchange capacity, aggregation, soil bulk density, microbial activity and soil tilth (Coulter et al., 2009). McCown and Jones (1992) referred to continual loss of SOC in smallholder farming systems as the "poverty trap". To get farmers out of this poverty trap, technology interventions that can improve SOC should be developed. The maize-mucuna rotations have the potential to improve $\mathrm{WP}_{\text {grain }}$, soil fertility and livestock feed. However adoption of a technology by farmers is not mainly based on its agronomic performance but by other factors/uses that would be important to the overall farm production and household needs (Becker et al., 1995). Some factors and uses considered by farmers are weed suppression, labor demands, seed availability, human food and livestock feed among others (Becker et al., 1995). Mucuna can be used to improve soil fertility, weed suppression and also as livestock feed (Nyambati, 2002). Green manures were introduced in Zimbabwe in the 1950s but constraints such as labor and seed unavailability caused low adoption in the smallholder farming systems (Jeranyama et al., 1997). With the current negative trends is soil fertility and also the high costs of inorganic fertilizers, there is therefore need to make such technologies to be accessible to the farmers.

\section{Conclusions}

The simulation results shows that the maize-mucuna rotation system has the potential to improve maize productivity and soil fertility in smallholder farming systems in the semi-arid areas of Zimbabwe. Simulation modeling provides a valuable framework for systems analysis of farming systems; they also assist as decision-making tools. However performance of the suggested alternative technologies need to be evaluated on-farm for attainable yields and also to evaluate other factors or uses of the crop, which might limit adoption by farmers. The technology is promising but as in the past adoption has been limited due to constraints such as labor demand and lack of seed among others, this is evidenced by low adoption or non-use of green manures despite improved attainable yields. With the current levels of soil fertility, cereal yields and the high cost of inorganic fertilizers, alternative sources needs to be sort and inclusion of forage legumes is one promising technology that can be evaluated for on-farm benefits e.g. use of forage legumes combined with crop residues to improve soil fertility and also as an adjunct to dry season feed shortages.

\section{Acknowledgements}

We would like to acknowledge BMZ for funding our research work through the International Water Management Institute (IWMI) and the International Crops Research Institute (ICRISAT).

\section{References}

Ahmed, M.M., Rohrbach, D.D., Gono, L.T., Mazhangara, E.P., Mugwira, L., Masendeke, D.D., Alibaba, S., 1997. Soil fertility management in communal areas of Zimbabwe:current practices, constraints and opportunities for change. Results of a Diagnostic Survey. Southern and Eastern Africa Region Working Paper No. 6. PO Box 776, ICRISAT, Bulawayo, Zimbabwe, pp. 1-19.

Akponikpe, I.P.B., Gerard, B., Michels, K., Beilders, C., 2010. Use of the APSIM model in long term simulation to support decision making regarding nitrogen management for pearl millet in the Sahel. European Journal of Agronomy 32, $144-154$.

Álvaro-Fuentes, J., Lampurlanés, J., Cantero-Martínez, C., 2009. Alternative crop rotations under Mediterranean no-tillage conditions: biomass, grain yield, and water-use efficiency. Agronomy Journal 101 (5), 1227-1234.

Baloyi, J.J., Ngongoni, N.T., Topps, J.H., Ndlovu, P., 1997. Chemical composition and degradability of Brachstegia spiciformois (musasa) leaves and stems harvested over 4 months from three sites in Zimbabwe. Animal Feed Science Technology 69, 179-186.

Becker, M., Ladha, J.K., Ali, M., 1995. Green manure technology: potential, usage, and limitations. A case study for lowland rice. Plant Soil 174, 181-194.

Cai, X., Rosegrant, M.W., 2003. World water productivity: Current situation and future options. In: Kijne, J.W., Barker, R., Molden, D. (Eds.), Water Productivity in Agriculture: Limits and Opportunities for Improvements. CAB International, pp. 163-178.

Chivenge, P.P., Dimes, J., Nhamo, N., Nzuma, J.K., Murwira, H.K., 2004. Evaluation of APSIM to simulate maize response to manure inputs in wet and dry regions of Zimbabwe. In: Delve. R.J., Probert, M.E. (Eds.), Modelling Nutrient Management in Tropical Cropping Systems. ACIAR Proceedings, vol. 114, pp. 85-91.

Cook, B.G., Pengelly, B.C., Brown, S.D., Donnelly, J.L., Eagles, D.A., Franco, M.A., Hanson, J., Mullen, B.F., Partridge, I.J., Peters, M., Schultze-Kraft, R., 2005. Tropical Forages: an interactive selection tool. [CD-ROM], CSIRO, DPI\&F(QId), CIAT and ILRI, Brisbane, Australia.

Coulter, J.A., Nafziger, E.D., Wander, M.M., 2009. Soil organic matter response to cropping systems and nitrogen fertilization. Agronomy Journal 101 (3), 592599.

Delve, R.J., Probert, M.E., Cobo, J.G., Ricaurte, J., Rivera, M., Barrios, E., Rao, I.M., 2009. Simulating phosphorus response in annual crops using APSIM: model evaluation on contrasting soil types. Nutrient Cycling in Agroecosystems 84 (3), 293-306.

FAO, 2002. Cattle and small ruminant production systems in sub-Saharan Africa - a systematic review. Rome, p. 68.

Giller, K.E., 2001. Nitrogen fixation in tropical cropping systems, second ed. CAB International, Wallingford, p. 458.

Giller, K.E., 2001. Nitrogen fixation in tropical cropping systems, $2^{\text {nd }}$ ed. CAB International, Wallingford, $458 \mathrm{p}$.

Haileslassie, A., Peden, D., Gebreselassie, T., Amede, T., Wagnew, A., Taddesse, G. 2009. Livestock water productivity in the Blue Nile Basin: assessment of farm scale heterogeneity. The Rangeland journal 31 (2), 213-222.

International Crops Research Institute for the Semi-Arid Tropics (ICRISAT), 2008. Crop-livestock Water Productivity Survey (Nkayi District, Zimbabwe).

Ikie, F.O., Schilz, S., Ogunyeni, S., Emechebe, A.M., 2006. Effect of soil sterility on soil chemical properties and sorghum performance under striga. World Journal of Agricultural Sciences 2 (4), 367-371.

Keating, B.A., Carberry, P.S., Hammer, G.L., Probert, M.E., Robertson, M.J., Holzworth, D., Huth, N.I., Hargreaves, J.N.G., Mainke, H., Hochman, Z., McLean, G., Verburg, K., Snow, V., Dimes, J.P., Silburn, M., Wang, E., Brown, S., Bristow, K.L., Asseng, S., Chapman, S., McCown, R.L., Freebairn, D.M., Smith, C.J., 2003. An overview of APSIM, a model designed for farming systems simulation. European Journal of Agronomy 18, 267-288.

Kumwenda, J.D.T., Gilbert, R., 1998. Biomass production by legume green manures on exhausted soils in Malawi: a soil fertility network trial. In: Waddington, S.R., Murwira, H.K., Kumwenda, J.D.T., Hikwa, D., Tagwira, F., (Eds.), Soil fertility research for smallholder maize-based systems in Malawi and Zimbabwe. SoilFertNet/CIMMYT, Harare, pp. 85-86.

Liu, J., Zehnder, A.J.B., Yang, H., 2008. Drops for crops: modelling crop water productivity on a global scale. Global NEST Journal 10 (3), 295-300.

Maasdorp, B.V., Titterton, M., 1997. Nutritional improvement of maize silage for dairying: mixed-crop silages from sole and intercropped legumes and a longseason variety of maize. 1. Biomass yield and nutritive value. Animal Feed Science Technology 69, 241-261.

Maasdorp, B.V., Jiri, O., Temba, E., 2004. Contrasting adoption, management, productivity and utilization of Mucuna in two different smallholder farming systems in Zimbabwe. In: Whitbread, A.M., Pengelly, B.C. (Eds.), Tropical 
Legumes for Sustainable Farming System in Southern Africa and Australia. ACIAR proceedings, vol. 114, pp. 153-163.

Mapfumo, P., Giller, K.E., 2001. Soil fertility management strategies and practices by Smallholder Farmers in semi-arid areas of Zimbabwe. In: International Crop Research Institute for the Semi-Arid Tropics (ICRISAT) with Permission from the Food and Agriculture Organization of the United Nation (FAO), pp. 1-43.

Masikati, P., 2006. Tillage and Manure Interactions under Dryland Cropping in Semi-arid Zimbabwe. Department of Soil Science and Agricultural Engineering, University of Zimbabwe, Harare, Zimbabwe. MPhil Thesis, 114p.

Masikati, P., 2011. Improving the water productivity of integrated crop-livestock systems in the semi-arid tropics of Zimbabwe An ex-ante analysis using simulation modeling. Department of Agriculture, Bonn University, Bonn, Germany. PhD thesis, p. 153

McCown, R.L., Jones, R.K., 1992. Agriculture of semi-arid eastern Kenya: problems and possibilities. In: Probert, M.E. (Ed.), A search for strategies for sustainable dryland cropping in semi-arid eastern Kenya. ACIAR Proceedings No. 41, pp. $8-$ 14.

McCown, R.L., Hammer, G.L., Hargreaves, J.N.G., Holzworth, D.P., Freebairn, D.M., 1996. APSIM: A novel software system for model development, model testing, and simulation in agricultural research. Agricultural Systems 50, 255-271.

Mpairwe, D., 2005. Undernutrition in dairy ruminants and intervention options for coping with feed scarcity in smallholder production systems in Uganda. In: Ayantunde, A.A., Fernandez-Rivera, S., McCrabb, G. (Eds.), Coping with feed scarcity in smallholder livestock systems in developing countries Animal Sciences Group, Wageningen UR, Wageningen, The Netherlands, University of Reading, Reading, UK, ETH (Swiss Federal Institute of Technology), Zurich, Switzerland, and ILRI (International Livestock Research Institute), Nairobi, Kenya. Mugwira, L.M., Shumba, E.M., 1986. Rate of manure applied in some communal areasand then effect on plant growth and maize grain yields. Zimbabwe Agriculture Journal, 83, pp. 99-104.

Mugwira, L.M., Shumba, E.M., 1986. Rate of manure applied in some communal areasand then effect on plant growth and maize grain yields. Zimbabwe Agriculture Journal 83, 99-104.

Mugwe, J., Mugendi, D., Okoba, B., Tuwei, P., O’Neill, M., 2004. Soil conservation and fertility improvement using leguminous shrubs in Central Highlands of Kenya: NARFP Case Study. In: Bationo, A. (Ed.), Managing Nutrient Cycles to Sustain Soil Fertility in Sub-Saharan Africa, pp. 277-297.

Mustafa, Y., Grando, S., Maatougui, M., 2008. Optimal agronomic practices to improve water productivity for barley in Highlands of Eritrea. In: Paper Presented at the CPWF Workshop on Increasing Water Productivity of Rainfed Cropping Systems. Tamale, Ghana, September 2008.

Ncube, B., Dimes, J.P., van Wijk, M.T., Twomlow, S.J., Giller, K.E., 2008. Productivity and residual benefits of grain legumes to sorghum under semi-arid conditions in south-western Zimbabwe: unravelling the effects of water and nitrogen using a simulation model. Field Crops Research. http://dx.doi.org/10.1016/ j.fcr.2008.08.001.

Ngongoni, T.N., Mwale, M., Mapiye, C., Moyo, M.T. Hamudikuwanda, H., Titterton, M., 2007. Evaluation of cereal-legume intercropped forages for smallholder dairy production in Zimbabwe. Livestock Research for Rural 19 (9), 1-11.

Nyambati, E.M., 2002. Management and Nutritive Evaluation of Mucuna pruriens and Lablab purpureus-maize Intercrops in the Sub-humid Highlands of Northwestern Kenya. PhD thesis, p. 234.

Nzuma, J.K., Murwira, H.K., Mpepereki, S., 1998. An evaluation of the agronomic effectiveness of low rates of cattle manure and combinations of inorganic $\mathrm{N}$ in Zimbabwe. In: Waddington, S.R., Murwira, H.K., Kumwenda, J.D.T., Hikwa, D., Tagwira, F. (Eds.), Soil Fertility Research for Maize-based Farming Systems in Malawi and Zimbabwe. Proceedings of the Soil Fertility Network Results and Planning Workshop. Held from 7-11 July 1997 at Africa University Mutare, Zimbabwe, pp. 179-182.
Omotayo, O.E., Chukukwa, K.S., 2009. Soil fertility restoration techniques in suSaharan Africa using organic resources. African Journal of Agricultural Research 4 (3), 144-150.

Probert, M.E., 2007. Modelling Minimum Residue Thresholds for Soil Conservation Benefits in the Tropical, Semi-arid Cropping Systems. Canberra, ACIAR Technical Reports No. 66, 34p.

Probert, M.E., Dimes, J.P., 2004. Modelling release of nutrients from organic resources using APSIM. In: Delve, R.J., Probert, M.E., (Eds.), Modelling nutrient management in tropical cropping systems. ACIAR Proceedings. 114, pp. 25-31.

Probert, M.E., Dimes, J.P., Keating, B.A., Dalal, R.C., Strong, W.M., 1998. APSIM's water and nitrogen modules and simulation of the dynamics of water and nitrogen in fallow systems. Agricultural Systems 56, 1-28.

Reuter, D.J., Edwards, D.G., Wilhelm, N.S., 1997. Temperate and Tropical crops. In Plant analysis: an interpretation manual, second edition (Eds.), Reuter, D.J., Robinson, J.B., pp. 83-284.

Robertson, M.J., Sakala, W., Benson, T., Shamudzarira, Z., 2005. Simulating the response of maize to previous velvet bean (Mucuna pruriens) crop and nitrogen fertilizer in Malawi. Field Crops Research 91, 91-105.

Rockström, J., Barron, J., Fox, P., 2003. Water productivity in rain-fed agriculture: challenges and opportunities for smallholder farmers in drought-prone tropical agroecosystems. In: Kijne, J.W., Barker, R., Molden, D. (Eds.), Limits and Opportunities for Improvement, pp. 145-162.

Sakala, W.D., Ligowe, I., Kayira, D., 2003. Mucuna-maize rotations and short fallows to rehabilitate smallholder farms in Malawi. In: Waddington, S.R. (Ed.), Grain Legumes and Green Manures for Soil Fertility in Southern Africa: Taking Stock of Progress'. (Soil Fert Net-CIMMYT, Harare, Zimbabwe), pp. 161-163.

Sanchez, P.A., Shepherd, K.D., Soule, M.J., Place, F.M., Buresh, R.J., Izac, A.M.N. Mokwunye, A.U., Kwesiga, F.R., Ndiritu, C.G., Woomer, P.L., 1997. Soil fertility replenishment in Africa: an investment in natural resource capital. In: Buresh R.J., Sanchez, P.A., Calhoun, F. (Eds.), Replenishing Soil Fertility in Africa, SSSA Special Publication 51. (Soil Science Society of America, Madison, WI, USA), pp. $1-46$.

Shamudzarira, Z 2003. Evaluating mucuna green manure technologies in Southern Africa through crop simulation modelling (87-91). In: Waddington, S.R. (Ed.), Grain legumes and green manures for soil fertility in Southern Africa: taking stock of progress. 2003. Proceedings of a conference held 8-11 October 2002 at the Leopard Rock Hotel, Vumba, Zimbabwe. Soil Fert Net and CIMMYTZimbabwe, Harare, Zimbabwe, p. 246p.

Twomlow, S., Rohrbach, D., Dimes, J., Rusike, J., Mupangwa, W., Ncube, B., Hove, L. Moyo, M., Mashingaidze, N., Maphosa, P., 2008. Micro-dosing as a pathway to Africa's Green Revolution: evidence from broad-scale on-farm trials. Nutrient cycling in Agroecosystems. http://dx.doi.org/10.1007/s10705-008-9200-4.

Waddington, S., Sakala, W.D., Mekuria, M., 2004. Progress in lifting soil fertility in Southern Africa. In: Proceedings of the 4th International Crop Science Congress, "New directions for a diverse planet", 26 September-1 October 2004 Brisbane, Australia. Published on CDROM.

Weber, G. 1996. Legume based technologies for African savannas: challenges for research and development. Biological Agriculture and Horticulture 13, 309333.

Whitbread, A.M., Jiri, O., Maasdorp, B., 2004. The effect of managing improved fallows of Mucuna pruriens on maize production and soil carbon and nitrogen dynamics in sub-humid Zimbabwe. Nutrient Cycling in Agroecosystems 69, 5971

Woyengo, T.A., Gachuiri, R.G., Wahome, R.G., Mbugua, P.N., 2004. Effect of protein supplementation and urea treatment on utilization of maize stover by red Maasai sheep. South African Journal of Animal Science 34, 23-30.

Zingore, S., 2006. Exploring Diversity within Smallholder Farming Systems in Zimbabwe: Nutrient Use and Resource Management Strategies for Crop Production. PhD Thesis, p. 258. 